Article

\title{
Non-Additive Effects of Forest Litter on Flammability
}

\author{
Angela G. Gormley, Tina L. Bell and Malcolm Possell * (10) \\ School of Life and Environmental Sciences, University of Sydney, Sydney, NSW 2006, Australia; \\ agor9300@uni.sydney.edu.au (A.G.G.); tina.bell@sydney.edu.au (T.L.B.) \\ * Correspondence: malcolm.possell@sydney.edu.au
}

Received: 20 March 2020; Accepted: 10 May 2020; Published: 12 May 2020

check for updates

\begin{abstract}
Forest litter is a fuel component that is important for the propagation of fire. Data describing fuel load, structure and fuel condition were gathered for two sites of Sydney Coastal Dry Sclerophyll Forest, a common vegetation type in the Sydney Basin, Australia. Surface litter from the sites was sorted into its constituent components and used to establish which component or mixture of components were the most flammable using several metrics. A general blending model was used to estimate the effect the different mixtures had on the response of the flammability metrics and identify non-additive effects. Optimisation methods were applied to the models to determine the mixture compositions that were the most or least flammable. Differences in the flammability of the two sites were significant and were driven by Allocasuarina littoralis. The presence of A. littoralis in litter mixtures caused non-additive effects, increasing the rate of flame spread and flame height non-linearly. We discuss how land managers could use these models as a tool to assist in prioritising areas for hazard reduction burns and how the methodology can be extended to other fuel conditions or forest types.
\end{abstract}

Keywords: prescribed burn; bushfire; land management; simplex centroid design; general blending model; non-additive effect

\section{Introduction}

A major bushfire can cost hundreds of millions of dollars because of fire suppression, insurance costs, deaths, destroyed homes and damage to urban infrastructure including electricity and water supplies, and road and rail networks [1,2]. Treatments to mitigate the risk of bushfires are expensive so land managers must weigh up the level of risk with costs incurred for preventative activities. For example, average annual suppression costs for the state-based rural fire agency to operate within a local district in New South Wales (NSW), Australia, with an area of close to $450 \mathrm{~km}^{2}$, are estimated at approximately $\$ 3.7$ million (US) per year $[3,4]$. Official enquiries into devastating bushfires have prompted investigations to prevent widespread destruction and loss of life. One of the strongest recommendations that came from the 2009 Victorian Bushfires Royal Commission into the "Black Saturday" fires in Victoria, Australia was to increase the areas of prescribed burns [5]. This was in response to the series of fires that ignited on or around Saturday, 7th February 2009 resulting in 173 fatalities [5]. Hence, fuel management policies legislated in Victoria now enable greater areas to be burnt to reduce fuel loads to potentially save lives and strategic assets. The recent fires in south-east Australia during the 2019-2020 bushfire season burned at least 5.4 million hectares in NSW, with the loss of over 3000 homes and 33 lives [6]. Therefore, risk mitigation treatments cannot realistically be used across the landscape because the areas are too large, and the costs become prohibitive. A better understanding of flammability and fire behaviour of fire-prone forests and woodlands will help land managers prioritise fire mitigation treatments. Land managers need to have integrated fuel treatment planning and optimisation models that are easy to learn and use while providing practical applications in the 
forests and woodlands they manage [7]. Because fire shapes vegetation globally, a fundamental goal of functional ecology is to scale from plant traits to ecosystem effects [8]. The mechanistic basis for scaling has been elusive because previous studies from laboratories, mathematical models and field tests have produced inconsistent results [9]. Recent studies have investigated how litter components and plant species influence flammability of fuels (e.g., Della Rocca et al. [10], de Maghalães and Schwilk [11]).

A non-additive effect with regard to the flammability of fuels is when a component of the fuel load dominates the overall flammability to a greater extent than the proportion of its weight in the mixture [12]. A standard methodology can be used to assess the flammability of litter mixtures and identify non-additive effects. The simplex centroid design (SCD) is a multivariate design of experiment (DOE) commonly used in analytical chemistry experiments when optimisation is an essential stage to determine the value that each factor must provide to ensure an optimal outcome [13]. The advantages of using a multivariate DOE, instead of univariate procedures, is that it is more efficient, requires fewer materials, and provides a lot of information while reducing the number of experiments needed for multiple response optimisation [13]. In addition, multivariate DOE varies all the levels of the factors involved simultaneously, which enables a mathematical model to be created to connect the response to the experimental conditions. These responses at any point of the experimental domain can be predicted once the coefficients of the model have been estimated [13]. Furthermore, the interactions between the factors with the responses can be studied [13].

Litter in forests and woodlands is the primary fuel for surface fires and influences fire behaviour because of its chemistry, ubiquity and mass $[14,15]$. Fuel flammability describes the capacity of forest litter to ignite and combust [15]. Litter fractions (leaves, twigs, bark and decomposed material) are not generally independent from each other because they are mixed together in the field and are generally collected as a composite sample. A mixture design that allows the variation of the ratios among the litter fractions is necessary. The SCD enables this to occur since its experimental design has a domain with as many vertices as components and a space with dimensionality equal to the number of components minus one [16]. Hence for forest and woodland litter fuels, if there are three litter fractions then this is represented with a two-dimensional triangle. If these three litter fractions are twigs, leaves and decomposed material, then each litter fraction will occupy a vertex. Every point within this triangle represents proportions of the litter fractions. For example, the centre of the triangle is a mixture of one-third twigs, one-third leaves and one-third decomposed material. These proportions affect the measured response, which can be used to describe flammability.

Empirical data to characterise the physical and chemical attributes of litter include semi-quantitative measures of fuel load and structure (e.g., fuel hazard score and percent cover score, [17]) and quantitative measures of fuel condition (e.g., surface litter depth, bulk density and soil moisture). Surface litter can be sorted into fractions (e.g., whole and partial leaves, bark, flowers and flower parts and twigs, partially and fully decomposed organic material) and used to determine which component or mixture of components are the most flammable. The SCD method can be used to determine suitable mixtures of fuel fractions for testing flammability metrics (e.g., ignitability, combustability, consumability and sustainability; $[18,19])$ and a general blending model (GBM) [20] can be used to determine the best statistical model fit for those metrics. Measures of flammability could include how long it takes for fuel to ignite and then completely burn, how long flames are visible and how big they are, how quickly the fire can spread and how much fuel is consumed. Modelled data can then be optimised to find the maximum or minimum values for a measure and the corresponding proportions of litter fuels for those values.

In this study, we examine two sites, both classified as Sydney Coastal Dry Sclerophyll Forest, and assess whether they differ in structure and fire risk. Through a series of laboratory experiments based upon the litter collected at these sites, we assess whether it is possible to model the flammability of different litter mixtures from this forest type using the SCD method and GBM, and identify fuel mixtures that may inform land managers of areas to prioritise for treatment. We discuss the caveats of this approach and its applicability to other forest types. 


\section{Materials and Methods}

\subsection{Site Description}

Two sites located on public land were used in this study: one located near Bay Road, Arcadia

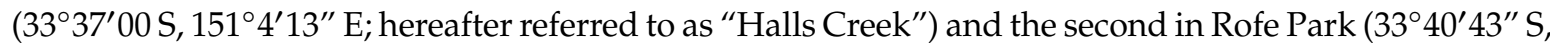
$151^{\circ} 6^{\prime} 5^{\prime \prime}$ E; hereafter referred to as "Rofe Park") in New South Wales, Australia (Figure 1). The study sites at Halls Creek and Rofe Park were chosen as being representative of long unburnt Sydney Coastal Dry Sclerophyll Forest [21]. Sydney Coastal Dry Sclerophyll Forest is typically associated with infertile soils derived from Hawkesbury Sandstone in deeply dissected terrain [22] and is the dominant forest type surrounding the Sydney Greater Metropolitan Region [21]. The elevation of study sites ranged from 142 to $206 \mathrm{~m}$ above sea level and the general study area has long-term maximum monthly temperatures over $30^{\circ} \mathrm{C}$ during the summer months (December and January) and minimum temperatures of $4-6{ }^{\circ} \mathrm{C}$ in the winter months (July and August). Long-term mean annual rainfall for the two sites ranged from 562 to $2844 \mathrm{~mm}$ [23]. Both sites were considered to be long unburnt; one plot in the Halls Creek study site was last burned in planned fires in 1990 and one plot at Rofe Park was burnt in 1996 [24].

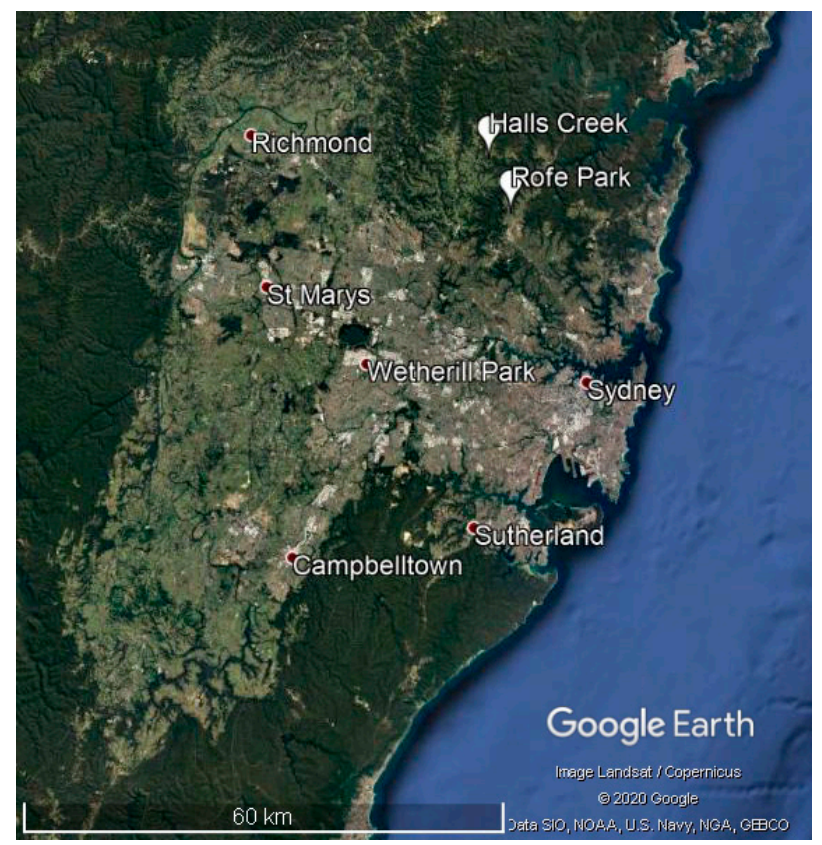

Figure 1. The location of the field sampling sites relative to areas within the Greater Metropolitan Region of Sydney, NSW, Australia.

\subsection{Field Sampling Description}

Three $50 \mathrm{~m}$ transects were established within both study sites. The main overstorey and midstorey tree species associated with each transect were recorded. The "nearest individual" method was used for estimation of tree density [25]. For this, the five trees nearest the mid-point of the transect (25 $\mathrm{m})$ with diameters greater than $10 \mathrm{~cm}$ were identified and the distance from the mid-point and their diameters were measured at breast height.

For each transect, a visual assessment of the vertical fuel structure was done at the 5, 15, 25, 35 and $45 \mathrm{~m}$ points along the transect. This involved identification of five fuel layers: surface fuel (litter), near-surface fuel, elevated fuel, intermediate tree canopy and overstorey tree canopy. Two subjective ratings, the fuel hazard score (FHS; a categorical score that represents a subjective assessment of the flammability of each layer based on the type of bark, the density and morphological development of the vegetation and the accumulation of litter [17]) and percent cover score (PCS; a rating of the cover of 
each fuel layer into one of five categories; [17]) were assigned to each fuel layer. These methods are discussed in detail in [17].

\subsection{Collection, Sorting and Preparation of Litter}

At five sample collection points along each transect (i.e., 5, 15, 25, 35 and $45 \mathrm{~m}$ ), a circular sampling ring $\left(0.1 \mathrm{~m}^{2}\right)$ was placed on the ground and litter depth $(\mathrm{mm})$ measured at six random points within the ring. The live vegetation was removed, and the litter was collected down to the mineral soil layer.

Litter samples were dried in a fan-forced convection drying oven (Model TD-78T-2-D, Thermoline Scientific, Wetherill Park, NSW Australia) at $60^{\circ} \mathrm{C}$ for $48 \mathrm{~h}$ and weighed. Dried litter samples were sorted into separate components and reweighed. Leaves, cladodes of Allocasuarina littoralis (hereafter referred to as "cladodes"), twigs (less than $6 \mathrm{~mm}$ in diameter) and other materials (such as bark, flower parts and woody fruits; hereafter referred to as "other") were separated from the decomposed fraction by passing through a $9 \mathrm{~mm}$ sieve. Soil was removed from the decomposed fraction by passing through a $2 \mathrm{~mm}$ sieve and adjusting values according to silica content [26]. Four litter fractions were identified for samples from Halls Creek (i.e., leaves, twigs, decomposed material and other) but the presence of cladodes at Rofe Park meant five fractions for this site. Bulk density of the various components of the litter fractions was calculated using the dry weight of each fraction, corresponding to total litter depth and the area of the sampling ring.

The SCD method was used to create the experimental design to determine which litter component or mixture was the most flammable. The mixture proportions were determined using the "mixexp" $\mathrm{R}$ package [27] in the R programming language [28]. This is appropriate for standard mixture designs in unconstrained regions [29,30]. For Halls Creek, a SCD with four litter components resulted in 15 mixtures (Table 1). For Rofe Park, five litter components gave an SCD design with 31 mixtures (Table 2). Representative mixtures were created from bulked litter fractions for each site and stored in sealed, airtight containers until burnt. These representative mixtures were given a sample name based upon their origin, Halls Creek $(\mathrm{H})$ or Rofe Park $(\mathrm{R})$, and the litter that they contained - other $(\mathrm{O})$, twigs (T), leaves (L), decomposed material (D), and cladodes (C). For example, a mixture of leaves and twigs from Halls Creek was named HTL, and a mixture of cladodes and decomposed material from Rofe Park was named RCD.

Table 1. Key to flammability combinations for litter from Halls Creek $(\mathrm{H})$ : other $(\mathrm{O})$, twigs $(\mathrm{T})$, leaves (L), decomposed material (D). The values represent the proportion of each litter component within a mixture.

\begin{tabular}{cccccc}
\hline Mixture Number & Sample Name & Other & Twigs & Leaves & Decomposed Material \\
\hline & & $\mathbf{( x 1 )}$ & $\mathbf{( x 2 )}$ & $\mathbf{( x 3 )}$ & $\mathbf{( x 4 )}$ \\
\hline 1 & HO & 1 & - & - & - \\
2 & HT & - & 1 & - & - \\
3 & HL & - & - & 1 & - \\
4 & HD & - & - & - & 1 \\
\hline 5 & HOT & 0.5 & 0.5 & - & - \\
6 & HOL & 0.5 & - & 0.5 & - \\
7 & HOD & 0.5 & - & - & - \\
8 & HTL & - & 0.5 & 0.5 & 0.5 \\
9 & HTD & - & 0.5 & - & 0.5 \\
10 & HLD & - & - & 0.5 & - \\
\hline 11 & HOTL & $1 / 3$ & $1 / 3$ & $1 / 3$ & $1 / 3$ \\
12 & HOTD & $1 / 3$ & $1 / 3$ & - & $1 / 3$ \\
13 & HOLD & $1 / 3$ & - & $1 / 3$ & 0.25 \\
\hline 14 & HTLD & - & $1 / 3$ & $1 / 3$ & \\
\hline 15 & HOTLD & 0.25 & 0.25 & 0.25 & \\
\hline
\end{tabular}


Table 2. Key to flammability combinations for litter from Rofe Park (R): Allocasuarina littoralis cladodes $(\mathrm{C})$, other $(\mathrm{O})$, twigs $(\mathrm{T})$, leaves $(\mathrm{L})$, decomposed material $(\mathrm{D})$. The values represent the proportion of each litter component within a mixture.

\begin{tabular}{|c|c|c|c|c|c|c|}
\hline Mixture Number & Sample Name & Casuarina & Other & Twigs & Leaves & Decomposed Material \\
\hline & & $(x 1)$ & $(\mathrm{x} 2)$ & $(x 3)$ & $(x 4)$ & $(x 5)$ \\
\hline 1 & $\mathrm{RC}$ & 1 & - & - & - & - \\
\hline 2 & $\mathrm{RO}$ & - & 1 & - & - & - \\
\hline 3 & RT & - & - & 1 & - & - \\
\hline 4 & RL & - & - & - & 1 & - \\
\hline 5 & $\mathrm{RD}$ & - & - & - & - & 1 \\
\hline 6 & $\mathrm{RCO}$ & 0.5 & 0.5 & - & - & - \\
\hline 7 & $\mathrm{RCT}$ & 0.5 & - & 0.5 & - & - \\
\hline 8 & RCL & 0.5 & - & - & 0.5 & - \\
\hline 9 & RCD & 0.5 & - & - & - & 0.5 \\
\hline 10 & ROT & - & 0.5 & 0.5 & - & - \\
\hline 11 & ROL & - & 0.5 & - & 0.5 & - \\
\hline 12 & ROD & - & 0.5 & - & - & 0.5 \\
\hline 13 & RTL & - & - & 0.5 & 0.5 & - \\
\hline 14 & RTD & - & - & 0.5 & - & 0.5 \\
\hline 15 & RLD & - & - & - & 0.5 & 0.5 \\
\hline 16 & RCOT & $1 / 3$ & $1 / 3$ & $1 / 3$ & - & - \\
\hline 17 & RCOL & $1 / 3$ & $1 / 3$ & - & $1 / 3$ & - \\
\hline 18 & RCOD & $1 / 3$ & $1 / 3$ & - & - & $1 / 3$ \\
\hline 19 & RCTL & $1 / 3$ & - & $1 / 3$ & $1 / 3$ & - \\
\hline 20 & RCTD & $1 / 3$ & - & $1 / 3$ & - & $1 / 3$ \\
\hline 21 & RCLD & $1 / 3$ & - & - & $1 / 3$ & $1 / 3$ \\
\hline 22 & ROTL & - & $1 / 3$ & $1 / 3$ & $1 / 3$ & - \\
\hline 23 & ROTD & - & $1 / 3$ & $1 / 3$ & - & $1 / 3$ \\
\hline 24 & ROLD & - & $1 / 3$ & - & $1 / 3$ & $1 / 3$ \\
\hline 25 & RTLD & - & - & $1 / 3$ & $1 / 3$ & $1 / 3$ \\
\hline 26 & RCOTL & 0.25 & 0.25 & 0.25 & 0.25 & - \\
\hline 27 & RCOTD & 0.25 & 0.25 & 0.25 & - & 0.25 \\
\hline 28 & RCOLD & 0.25 & 0.25 & - & 0.25 & 0.25 \\
\hline 29 & RCTLD & 0.25 & - & 0.25 & 0.25 & 0.25 \\
\hline 30 & ROTLD & - & 0.25 & 0.25 & 0.25 & 0.25 \\
\hline 31 & RCOTLD & 0.2 & 0.2 & 0.2 & 0.2 & 0.2 \\
\hline
\end{tabular}

\subsection{Flammability Testing}

Flammability testing was performed using a methodology adapted from Plucinski and Anderson [31]. Litter mixtures were placed into a foil-lined pan (diameter $28 \mathrm{~cm}$ ) and the litter depth was measured in five different places. Litter depth, dry litter weight and the area encompassed by the pan were used to calculate the bulk density of mixtures. A cotton ball soaked with $1 \mathrm{~mL}$ of methylated spirits was placed in the middle of each mixture and lit with a gas lighter. As the cotton ball ignites the top of the fuel bed, this method has been deemed to be appropriate for simulating ignition from a drip torch, aerial incendiaries and flaming firebrands [31]. A ruler was positioned next to the pan to measure vertical flame height (VFH) to the nearest $0.01 \mathrm{~m}$. Time-to-ignition (TTI; time taken to produce visual flaming), duration of visual flaming (DVF; amount of time flames were visible) and burn to completion (BTC; time taken from ignition to the visible absence of flaming or smouldering) were recorded to the nearest second. The rate of spread (RS; the rate at which burning migrated from the centre to the edge of the pan) and volume of the fuel consumed (VC) were calculated from these values and other measurements (litter depth and size of pan). After burning, the remaining sample was weighed to determine the residual mass fraction (RMF). A complete description of all these flammability metrics can be found in Table A1. 


\subsection{Response Surface Modelling of Flammability Measures}

For the flammability variables measured, the statistical model of Brown et al. [20] (general blending model-GBM) was fitted across the SCD designs to generate response surfaces and corresponding polynomial equations to describe those responses. The GBM maximises the fit of the response surface by changing the value of the exponents within the polynomial equations generated (labelled "Coefficients" in the Results section). The model of best fit for each variable at each site was selected using the Akaike second-order information criterion for small sample sizes ( $\mathrm{AIC}_{\mathrm{c}} ;$ " $\mathrm{AIC}_{\mathrm{cmodavg}}$ " package from the $\mathrm{R}$ programming language and statistical environment [32]).

Several statistics related to the goodness-of-fit of the model are also reported. The "Pr" values indicate the statistical significance of the flammability effect by the coefficients. Pr values of less than 0.05 were considered statistically significant and only these values are provided. "Std Error" is the

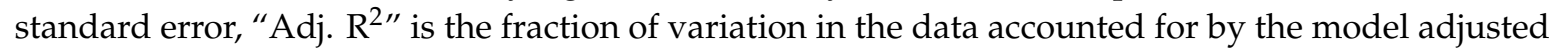
for the number of model terms. The $p$-values summarise the evidence against the null hypothesis that there is no relationship between the metric and the predictor variable tested.

For each flammability metric, individual coefficients and an equation with more than one coefficient are provided. If an individual coefficient had a statistically significant positive estimate value and a non-linear equation with the same individual coefficient in the mixture is also positive, then this coefficient was considered to have a non-additive flammability effect on the litter mixture.

\subsection{Model Optimisation}

To identify the proportions of the leaf components that would produce the maximum or minimum values for each measured flammability metric, optimisations of the GBM were run using the R program "nloptr" [33] with the local derivative-free Constrained Optimization by Linear Approximation (COBYLA) algorithm [34] or the Augmented Lagrangian algorithm (AUGLAG) [35,36], with local solver "lbfgs", if the COBYLA algorithm failed. If there was a perfect fit of the GBM model to the observed data, the minima and maxima of the GBM model would equal those of the observations. Therefore, the proportions of the different fuel fractions that produced observed maxima and minima were used as the starting point for the optimisation algorithm. As it is possible to produce identical maxima or minima values for certain measurements with different mixtures (e.g., TTI because of non-negativity constraints), optimisations of the GBM models were repeated from different starting points to identify if there was either a global solution or several local solutions.

\section{Results}

\subsection{Study Site Characteristics}

At the Rofe Park study site, dominant overstorey and midstorey tree species included Eucalyptus haemastoma, E. pipperita, Angophora costata, Banksia serrata, Allocasuarina littoralis, Cerapetalum gummifera and Corymbia gummifera. Dominant overstorey and midstorey tree species at Halls Creek included E. haemastoma, Corymbia eximia, Banksia serrata, Leptospermum trinervium and Cerapetalum gummifera. The average tree density at Halls Creek was $1358 \pm 811$ trees per ha ${ }^{-1}$ and that at Rofe Park was $1198 \pm 400$ trees per ha ${ }^{-1}$. Other physical measurements and visual assessments of fuel from Halls Creek and Rofe Park are provided in Table 3. 
Table 3. Physical measurements and visual assessments of litter from Halls Creek and Rofe Park: litter depth, fuel height, bulk density, fuel hazard score (FHS) and percent cover score (PCS).

\begin{tabular}{ccc}
\hline Variable & Halls Creek & Rofe Park \\
\hline Litter depth $(\mathrm{mm})$ & $46 \pm 17$ & $75 \pm 31$ \\
Near surface fuel height $(\mathrm{m})$ & $0.1 \pm 0.1$ & $1.0 \pm 0.2$ \\
Elevated fuel height $(\mathrm{m})$ & $2.9 \pm 0.3$ & $2.5 \pm 0.7$ \\
\hline Litter bulk density $\left(\mathrm{kg} \mathrm{m}^{-3}\right)$ & $20.0 \pm 5.3$ & $25.7 \pm 10.3$ \\
\hline Surface FHS & $3.3 \pm 0.5$ & $3.7 \pm 0.5$ \\
Near surface FHS & $2.7 \pm 0.3$ & $2.2 \pm 0.4$ \\
Elevated FHS & $1.7 \pm 0.2$ & $1.6 \pm 0.5$ \\
Bark FHS & $2.7 \pm 0.6$ & $2.0 \pm 0.0$ \\
\hline Surface PCS & $3.2 \pm 0.4$ & $3.4 \pm 0.2$ \\
Near surface PCS & $2.1 \pm 0.7$ & $2.6 \pm 0.7$ \\
Elevated PCS & $1.9 \pm 0.2$ & $1.5 \pm 0.6$ \\
Canopy PCS & $1.6 \pm 0.2$ & $2.4 \pm 0.2$ \\
\hline
\end{tabular}

\subsection{Measures of Flammability}

Bulk density (BD) of litter mixtures used in the flammability testing was the greatest for the twigs from Halls Creek (Table 4) and for the decomposed fraction from Rofe Park (RD) (Table 5). The lowest BD for both sites was leaves from Halls Creek (HL) and cladodes from Rofe Park (RC).

Time-to-ignition (TTI) was generally rapid for mixtures that contained leaves. The decomposed fraction from Halls Creek (HD) and other (RO) and decomposed fractions (ROD) from Rofe Park did not ignite or did not burn sufficiently to change the residual mass fraction (RMF) (Tables 4 and 5 for Halls Creek and Rofe Park, respectively).

Table 4. Flammability metrics for mixtures of litter collected from Halls Creek $(\mathrm{H})$ as specified by a simplex centroid design. The materials include: other (bark, hard woody fruits) $(\mathrm{O})$, twigs $(\mathrm{T})$, leaves (L), and decomposed material (D). Flammability metrics are: bulk density (BD), time-to-ignition (TTI), vertical flame height (VFH), rate of spread (RS), volume consumed (VC), residual mass fraction (RMF), burn to completion (BTC), and duration of visual flaming (DVF).

\begin{tabular}{ccccccccc}
\hline Sample & $\mathbf{B D}$ & TTI & VFH & RS & VC & RMF & BTC & DVF \\
\hline & $\left(\mathbf{k g ~ m}^{-\mathbf{3}}\right)$ & $\mathbf{( s )}$ & $\mathbf{( m )}$ & $\mathbf{( \mathbf { m ~ s } ^ { - \mathbf { 1 } } )}$ & $\mathbf{( \mathbf { m } ^ { \mathbf { 3 } } )}$ & $\mathbf{( \% )}$ & $\mathbf{( s )}$ & $\mathbf{( s )}$ \\
\hline HO & 28 & 2 & 0.22 & $2.50 \times 10^{-3}$ & $2.62 \times 10^{-4}$ & 21.38 & 202 & 200 \\
HT & 77 & 28 & 0.02 & 0 & 0 & 100 & 120 & 92 \\
HL & 15 & 7 & 0.30 & $1.80 \times 10^{-3}$ & $1.13 \times 10^{-3}$ & 62.88 & 179 & 172 \\
HD & 53 & 0 & 0 & 0 & 0 & 100 & 0 & 0 \\
\hline HOT & 31 & 6 & 0.16 & $4.10 \times 10^{-3}$ & $7.14 \times 10^{-4}$ & 0.14 & 97 & 91 \\
HOL & 21 & 1 & 0.24 & $1.90 \times 10^{-3}$ & $9.73 \times 10^{-4}$ & 38.71 & 223 & 222 \\
HOD & 36 & 3 & 0.01 & 0 & 0 & 100 & 5 & 2 \\
HTL & 26 & 7 & 0.20 & $1.50 \times 10^{-3}$ & $8.00 \times 10^{-4}$ & 45.41 & 335 & 328 \\
HTD & 74 & 24 & 0.01 & 0 & 0 & 100 & 171 & 147 \\
HLD & 37 & 5 & 0.12 & 0 & 0 & 100 & 110 & 105 \\
\hline HOTL & 27 & 7 & 0.08 & 0 & 0 & 100 & 91 & 112 \\
HOTD & 40 & 9 & 0.03 & 0 & 0 & 100 & 12 & 3 \\
HOLD & 28 & 1 & 0.01 & 0 & 0 & 100 & 0 & 0 \\
HTLD & 45 & 15 & 0 & 0 & 0 & 100 & 0 & 0 \\
\hline HOTLD & 24 & 1 & 0.11 & $2.50 \times 10^{-3}$ & 0 & 100 & 119 & 90 \\
\hline
\end{tabular}


Table 5. Flammability metrics for mixtures of litter collected from Rofe Park (R) as specified by a simplex centroid design. The materials include: Allocasuarina littoralis cladodes (C), other (bark, hard woody fruits) (O), twigs (T), leaves (L), and decomposed material (D). Flammability metrics are: bulk density (BD), time-to-ignition (TTI), vertical flame height (VFH), rate of spread (RS), volume consumed (VC), residual mass fraction (RMF), burn to completion (BTC), and duration of visual flaming (DVF).

\begin{tabular}{|c|c|c|c|c|c|c|c|c|}
\hline Sample & BD & TTI & VFH & RS & VC & RMF & BTC & DVF \\
\hline & $\left(\mathrm{kg} \mathrm{m}^{-3}\right)$ & (s) & $(\mathrm{m})$ & $\left(\mathrm{m} \mathrm{s}^{-1}\right)$ & $\left(\mathrm{m}^{3}\right)$ & $(\%)$ & (s) & (s) \\
\hline RC & 15 & 3 & 0.37 & $6.10 \times 10^{-3}$ & $1.33 \times 10^{-3}$ & 60.89 & 64 & 61 \\
\hline RO & 28 & 3 & 0.03 & 0 & $7.14 \times 10^{-4}$ & 33.77 & 115 & 112 \\
\hline RT & 29 & 35 & 0.10 & $9.00 \times 10^{-4}$ & $6.77 \times 10^{-4}$ & 3.52 & 193 & 158 \\
\hline RL & 21 & 3 & 0.15 & $1.90 \times 10^{-3}$ & $9.73 \times 10^{-4}$ & 50.2 & 170 & 167 \\
\hline RD & 95 & 25 & 0.05 & 0 & 0 & 100 & 0 & 0 \\
\hline RCO & 11 & 1 & 0.27 & $5.20 \times 10^{-3}$ & $1.86 \times 10^{-3}$ & 46.35 & 85 & 84 \\
\hline RCT & 11 & 2 & 0.33 & $6.70 \times 10^{-3}$ & $1.85 \times 10^{-3}$ & 61 & 147 & 145 \\
\hline RCL & 17 & 2 & 0.30 & $4.50 \times 10^{-3}$ & $1.18 \times 10^{-3}$ & 56.89 & 113 & 111 \\
\hline RCD & 13 & 1 & 0.31 & $4.20 \times 10^{-3}$ & $1.54 \times 10^{-3}$ & 26.3 & 90 & 89 \\
\hline ROT & 22 & 3 & 0.14 & 0 & 0 & 100 & 149 & 146 \\
\hline ROL & 24 & 2 & 0.16 & 0 & 0 & 100 & 146 & 144 \\
\hline ROD & 46 & 0 & 0 & 0 & 0 & 100 & 0 & 0 \\
\hline RTL & 24 & 3 & 0.18 & $2.20 \times 10^{-3}$ & $8.37 \times 10^{-4}$ & 6.51 & 184 & 181 \\
\hline RTD & 54 & 12 & 0.15 & 0 & 0 & 100 & 0 & 0 \\
\hline RLD & 32 & 11 & 0.15 & 0 & 0 & 100 & 120 & 109 \\
\hline RCOT & 12 & 1 & 0.24 & $3.40 \times 10^{-3}$ & $1.56 \times 10^{-3}$ & 58.71 & 234 & 233 \\
\hline RCOL & 11 & 1 & 0.38 & $4.50 \times 10^{-3}$ & $1.56 \times 10^{-3}$ & 85.34 & 206 & 205 \\
\hline RCOD & 14 & 1.5 & 0.29 & $5.90 \times 10^{-3}$ & $1.30 \times 10^{-3}$ & 23.09 & 114 & 112.5 \\
\hline RCTL & 8 & 2 & 0.43 & $4.70 \times 10^{-3}$ & $2.02 \times 10^{-3}$ & 47.35 & 207 & 205 \\
\hline RCTD & 19 & 2 & 0.18 & $2.30 \times 10^{-3}$ & $9.36 \times 10^{-4}$ & 21.8 & 159 & 157 \\
\hline RCLD & 10 & 1 & 0.41 & $5.00 \times 10^{-3}$ & $1.71 \times 10^{-3}$ & 42.67 & 140 & 139 \\
\hline ROTL & 19 & 3 & 0.20 & $2.00 \times 10^{-3}$ & $9.61 \times 10^{-4}$ & 9.09 & 137 & 134 \\
\hline ROTD & 27 & 40 & 0.12 & 0 & 0 & 100 & 0 & 0 \\
\hline ROLD & 28 & 8 & 0.11 & 0 & 0 & 100 & 87 & 79 \\
\hline RTLD & 34 & 12 & 0.06 & 0 & 0 & 100 & 92 & 80 \\
\hline RCOTL & 17 & 5 & 0.23 & $4.70 \times 10^{-3}$ & $1.22 \times 10^{-3}$ & 28.83 & 135 & 130 \\
\hline RCOTD & 28 & 3 & 0.12 & $1.80 \times 10^{-3}$ & 0 & 100 & 134 & 131 \\
\hline RCOLD & 22 & 4 & 0.28 & $4.70 \times 10^{-3}$ & $9.24 \times 10^{-4}$ & 21.91 & 85 & 81 \\
\hline RCTLD & 15 & 6 & 0.26 & $7.40 \times 10^{-3}$ & $1.40 \times 10^{-3}$ & 27.13 & 104 & 98 \\
\hline ROTLD & 49 & 8 & 0.04 & 0 & 0 & 100 & 30 & 22 \\
\hline RCOTLD & 19 & 3 & 0.23 & $3.70 \times 10^{-3}$ & $1.13 \times 10^{-3}$ & 10.58 & 95 & 92 \\
\hline
\end{tabular}

Some samples from both Halls Creek ( $60 \%$ of samples) and Rofe Park ( $35 \%$ of samples) ignited but went out so zero values were recorded for RS and VC and 100\% for RMF (Tables 4 and 5, respectively).

Rate of spread (RS) increased when cladodes were included in litter mixtures (Table 5) and, as a general comparison, RS was twice as fast for Rofe Park compared to Halls Creek. Litter mixtures from Halls Creek that were completely burnt and had the lowest RMF included twigs and other material (i.e., HO, HOT; Table 4) and for litter mixtures from Rofe Park contained twigs (i.e., RT, RTL, ROTL; Table 5).

\subsection{Flammability Modelling for Halls Creek}

Outputs from the results of the GBM are displayed in Table 6. Only the models with the smallest AICc values are shown. For all models, there was a good fit against the experimental data (adjusted $\mathrm{R}^{2}$ values ranging from 0.806 to 1$)$ and $p$-values of less than 0.05 , except for VC $(p=0.178)$. 
The bulk density (BD) model consisted of a mixture of exponents that were linear and to the power of 0.5 . There was a particularly strong negative non-additive effect between other and twig fractions (estimate $=-5.48 \times 10^{1}$ ). There was another very strong non-additive effect between twigs and leaves (estimate $=-1.36 \times 10^{3}$ ). This equation consisted of a mixture of constant and cubic exponents. All variables provided a significant positive contribution to $\mathrm{BD}$; twigs contributed the most and leaves contributed the least (Table 6).

The residual mass fraction (RMF) model had a very strong negative non-additive effect between other and twig fractions (estimate $=-8.70 \times 10^{3}$ ) and the equation consisted of constant and cubic exponents. A second potential model for other and twigs had a strong positive non-additive effect between these two litter components (estimate $=1.70 \times 10^{3}$ ), with the relevant equation consisting of a mixture of exponents that were cubic and to the power of 1.5 (Table 6).

Table 6. Model outputs for Halls Creek for bulk density (BD), burn to completion (BTC), residual mass fraction (RMF), rate of spread (RS), time-to-ignition (TTI), volume consumed (VC), vertical flame height $(\mathrm{VFH})$ and duration of visual flaming (DVF). $\mathrm{x} 1$ is other, $\mathrm{x} 2$ is twigs, $\mathrm{x} 3$ is leaves, $\mathrm{x} 4$ is decomposed material, statistical significance codes: 0 “***”, 0.001 “**”, 0.01 “*”, $\mathrm{AIC}_{\mathrm{c}}$ is the Akaike information criterion for small sample sizes.

\begin{tabular}{|c|c|c|c|c|c|c|c|}
\hline Metric & Coefficient & $\begin{array}{l}\text { Coefficient } \\
\text { Estimate }\end{array}$ & $\begin{array}{l}\text { Coeff. Std. } \\
\text { Error }\end{array}$ & $\operatorname{Pr}$ & Adj. $R^{2}$ & $p$ & $\begin{array}{l}\text { AIC }_{c} \\
\text { Value }\end{array}$ \\
\hline \multirow[t]{6}{*}{ BD } & $\mathrm{x} 1$ & $2.55 \times 10^{1}$ & $3.53 \times 10^{0}$ & $4.97 \times 10^{-5 * * *}$ & 0.989 & $2.78 \times 10^{-9}$ & 111 \\
\hline & $x 2$ & $7.97 \times 10^{1}$ & $3.83 \times 10^{0}$ & $6.34 \times 10^{-9 * * *}$ & & & \\
\hline & $\mathrm{x} 3$ & $1.49 \times 10^{1}$ & $3.41 \times 10^{0}$ & $1.79 \times 10^{-3} * *$ & & & \\
\hline & $\mathrm{x} 4$ & $5.38 \times 10^{1}$ & $3.20 \times 10^{0}$ & $4.25 \times 10^{-8 * * *}$ & & & \\
\hline & $\mathrm{I}\left(\mathrm{x} 1^{1} \times \mathrm{x} 2^{0.5} /(\mathrm{x} 1+\mathrm{x} 2+0.001)^{1}\right)$ & $-5.48 \times 10^{1}$ & $9.52 \times 10^{0}$ & $2.73 \times 10^{-4 * * *}$ & & & \\
\hline & $\mathrm{I}\left(\mathrm{x}^{3} \times \mathrm{x}^{3} /(\mathrm{x} 2+\mathrm{x} 3+0.001)^{0}\right)$ & $-1.36 \times 10^{3}$ & $3.26 \times 10^{2}$ & $2.44 \times 10^{-3 * *}$ & & & \\
\hline \multirow[t]{2}{*}{ BTC } & $\mathrm{x} 1$ & $1.35 \times 10^{2}$ & $5.47 \times 10^{1}$ & $4.27 \times 10^{-2} *$ & 0.808 & $3.20 \times 10^{-3}$ & 159 \\
\hline & $\mathrm{x} 3$ & $1.93 \times 10^{2}$ & $5.87 \times 10^{1}$ & $1.35 \times 10^{-2 *}$ & & & \\
\hline \multirow[t]{5}{*}{ RMF } & $\mathrm{x} 2$ & $8.67 \times 10^{1}$ & $1.59 \times 10^{1}$ & $4.03 \times 10^{-4 * * *}$ & 0.948 & $2.97 \times 10^{-6}$ & 154 \\
\hline & $\mathrm{x} 3$ & $6.26 \times 10^{1}$ & $1.44 \times 10^{1}$ & $1.82 \times 10^{-3 * *}$ & & & \\
\hline & $\mathrm{x} 4$ & $1.22 \times 10^{2}$ & $1.44 \times 10^{1}$ & $1.39 \times 10^{-5 * * *}$ & & & \\
\hline & $\mathrm{I}\left(\mathrm{x} 1^{3} \times \mathrm{x} 2^{3} /(\mathrm{x} 1+\mathrm{x} 2+0.001)^{0}\right)$ & $-8.70 \times 10^{3}$ & $2.30 \times 10^{3}$ & $4.30 \times 10^{-3} * *$ & & & \\
\hline & $\mathrm{I}\left(\mathrm{x} 1^{3} \times \mathrm{x} 2^{1.5} /(\mathrm{x} 1+\mathrm{x} 2+0.001)^{3}\right)$ & $1.70 \times 10^{3}$ & $6.96 \times 10^{2}$ & $3.75 \times 10^{-2} *$ & & & \\
\hline \multirow[t]{5}{*}{ RS } & $\mathrm{x} 1$ & $2.50 \times 10^{-1}$ & $3.45 \times 10^{-4}$ & $8.77 \times 10^{-4 * * *}$ & 1.0000 & $9.51 \times 10^{-4}$ & -161 \\
\hline & $\mathrm{x} 2$ & $5.70 \times 10^{-1}$ & $7.63 \times 10^{-4}$ & $8.51 \times 10^{-4 * * *}$ & & & \\
\hline & $x 3$ & $1.80 \times 10^{-1}$ & $3.46 \times 10^{-4}$ & $1.22 \times 10^{-3 * *}$ & & & \\
\hline & $\mathrm{I}\left(\mathrm{x} 2^{3} \times \mathrm{x} 3^{2.5} /(\mathrm{x} 2+\mathrm{x} 3+0.001)^{3}\right)$ & $-1.02 \times 10^{1}$ & $2.49 \times 10^{-2}$ & $1.55 \times 10^{-3 * *}$ & & & \\
\hline & $\mathrm{I}\left(\mathrm{x} 1^{3} \times \mathrm{x}^{3} /(\mathrm{x} 1+\mathrm{x} 3+0.001)^{0}\right)$ & $-1.60 \times 10^{0}$ & $2.72 \times 10^{-2}$ & $1.08 \times 10^{-2 *}$ & & & \\
\hline \multirow[t]{2}{*}{ TTI } & $\mathrm{x} 2$ & $2.42 \times 10^{1}$ & $3.09 \times 10^{0}$ & $2.65 \times 10^{-5 * * *}$ & 0.871 & $1.28 \times 10^{-4}$ & 98 \\
\hline & $x 4$ & $1.60 \times 10^{1}$ & $5.07 \times 10^{0}$ & $1.16 \times 10^{-2 *}$ & & & \\
\hline VC & \multicolumn{4}{|c|}{ No significant values } & 0.929 & $1.78 \times 10^{-1}$ & -128 \\
\hline \multirow[t]{2}{*}{ VFH } & $\mathrm{x} 1$ & $2.11 \times 10^{-1}$ & $3.84 \times 10^{-2}$ & $5.78 \times 10^{-4 * * *}$ & 0.903 & $1.07 \times 10^{-4}$ & -23 \\
\hline & $\mathrm{x} 3$ & $3.18 \times 10^{-1}$ & $3.88 \times 10^{-2}$ & $3.63 \times 10^{-5 * * *}$ & & & \\
\hline \multirow[t]{2}{*}{ DVF } & $\mathrm{x} 1$ & $1.38 \times 10^{2}$ & $5.27 \times 10^{1}$ & $3.41 \times 10^{-2 *}$ & 0.806 & $3.30 \times 10^{-3}$ & 158 \\
\hline & $\mathrm{x} 3$ & $1.88 \times 10^{2}$ & $5.66 \times 10^{1}$ & $1.26 \times 10^{-2 *}$ & & & \\
\hline
\end{tabular}

Twigs had the strongest positive effect on RS (estimate $=5.70 \times 10^{-1}$ ) and the next strongest positive effect was from the other fraction (estimate $=2.50 \times 10^{-1}$ ). There were non-additive effects with very significant negative interactions between twigs and leaves (estimate $=-1.02 \times 10^{1}$ ). The equation consisted of a mixture of exponents that were cubic and to the power of 2.5. There was another strong negative interaction between other and leaf fractions (estimate $=-1.60 \times 10^{0}$ ), with the equation consisting of a mixture of constant and cubic exponents (Table 6).

The time-to-ignition (TTI), burn to completion (BTC), volume consumed (VC), vertical flame height (VFH) and duration of visual flaming (DVF) models had no non-additive effects (Table 6). For TTI, twigs had the strongest positive effect (estimate $=2.42 \times 10^{1}$ ) and the decomposed fraction also had a strong positive effect $\left(\right.$ estimate $\left.=1.60 \times 10^{1}\right)$. For BTC, the other (estimate $=1.35 \times 10^{2}$ ) and leaf fractions (estimate $=1.93 \times 10^{2}$ ) provided a significant positive contribution. Although the 
volume consumed (VC) model was a good fit against the experimental data (adjusted $\left.\mathrm{R}^{2}=0.929\right)$ there were no significant equations and consequently the model was deemed insignificant $\left(p=1.78 \times 10^{-1}\right)$. For VFH, leaves had the strongest positive effect (estimate $=3.18 \times 10^{-1}$ ) and the other fraction also had a strong positive effect (estimate $=2.11 \times 10^{-1}$ ). The DVF model had strong positive effects from leaves $\left(\right.$ estimate $\left.=1.88 \times 10^{2}\right)$ and other $\left(\right.$ estimate $\left.=1.38 \times 10^{2}\right)$.

\subsection{Flammability Modelling for Rofe Park}

Outputs from the results of the GBM are displayed in Table 7. Only the models with the smallest AICc values are shown. For all models, there was a good fit against the experimental data (adjusted $\mathrm{R}^{2}$ values ranging from 0.833 to 0.973 ), they had $p$-values less than 0.05 , and they displayed non-additive effects. In the models for RMF, RS, VC, VFH and DVF, cladodes were the reason for the non-additive effects. Non-additive effects for the BTC, TTI and BD models were caused by leaves and decomposed material, twigs, and decomposed material, respectively. In addition to these non-additive effects, other components were also influential in the model responses both positively and negatively, and these influences are described below.

Further to the non-additive effects in the BD model, negative interactions were identified between the decomposed fraction and cladodes, leaves and other fractions with the strongest negative interaction with cladodes (estimate $\left.=-1.04 \times 10^{2}\right)($ Table 7$)$.

In the BTC model, the strongest positive effect of individual components was from twigs (estimate $=2.03 \times 10^{2}$ ). Cladodes had a very strong positive effect and there was a significant interaction between cladodes, other and twigs (estimate $\left.=4.93 \times 10^{5}\right)$. This model equation consisted of exponents that were cubic and to the power of 0.5 and 1.5 (Table 7).

In the RMF model, cladodes not only had a non-additive effect, but also with the leaves fraction had the strongest positive effect. By contrast, there was a negative interaction between twigs and the decomposed fraction (estimate $=-5.21 \times 10^{1}$ ) with the equation consisting of a mixture of exponents that were constant and to the power of 0.5 (Table 7).

The model of RS identified three of the components—cladodes, other and leaves-as having strong positive effects, and positive interactions were identified between cladodes and leaves, cladodes and twigs, and other and decomposed material. The interaction between cladodes and leaves was found to be strongly positive (estimate $=6.13 \times 10^{-1}$ ) and consisted of a mixture of exponents that were cubic and to the powers of 0.5 and 1.5. By contrast, there was a negative interaction between cladodes and other (estimate $=-1.07 \times 10^{-1}$ ) and the equation consisted of a mixture of exponents that were cubic and to the power of 0.5 (Table 7 ).

Twigs and decomposed material had a strong positive effect on the TTI model (estimate $=-1.10 \times 10^{3}$ ). The equation describing this interaction was a mixture of constant and cubic components. By contrast, there were very strong negative interactions between cladodes and decomposed (estimate $=-2.79 \times 10^{1}$ ) and the equation consisted of a mixture of exponents that were constant and to the power of 0.5 (Table 7).

In the models for VC, VFH and DVF, besides the non-additive effects caused by the cladodes, all five litter components had mainly strong positive effects. In the VC model, the decomposed fraction was influential (estimate $=1.56 \times 10^{-3}$ ) and there were positive interactions between cladodes and twigs (estimate $=3.91 \times 10^{-3}$ ). However, the interaction between twigs and decomposed was negative (estimate $=-5.24 \times 10^{-1}$ ) and consisted of constant and cubic exponents (Table 7). In the VFH model, a positive interaction was identified between cladodes and leaves (estimate $=2.71 \times 10^{2}$ ) and the equation consisted of a mixture of exponents that were constant, cubic and to the power of 2.5 (Table 7). In the DVF model, a positive interaction was identified between cladodes, other and twigs, and cladodes and leaves. By contrast, negative interactions were identified between leaves and decomposed material, cladodes, other and twigs, and cladodes and decomposed material. The interaction between leaves and decomposed material was strongly negative (estimate $=-2.24 \times 10^{2}$ ) and consisted of a mixture of exponents that were cubic and to the power of 0.5 and 1.5 (Table 7). 
Table 7. Model outputs for Rofe Park for bulk density (BD), burn to completion (BTC), residual mass fraction (RMF), rate of spread (RS), time-to-ignition (TTI), volume consumed (VC), vertical flame height (VFH) and duration of visual flaming (DVF). $x 1$ is cladodes, $x 2$ is other, $x 3$ is twigs, $x 4$ is leaves, $x 5$ is decomposed material, statistical significance codes: 0 “***”, 0.001 “*** 0.01 “*”, $\mathrm{AIC}_{\mathrm{C}}$ is the Akaike information criterion for small sample sizes.

\begin{tabular}{|c|c|c|c|c|c|c|c|}
\hline Metric & Coefficient & $\begin{array}{c}\text { Coefficient } \\
\text { Estimate }\end{array}$ & $\begin{array}{l}\text { Coeff. Std. } \\
\text { Error }\end{array}$ & $\operatorname{Pr}$ & $\begin{array}{l}\text { Adj. } \\
R^{2}\end{array}$ & $p$ & $\begin{array}{l}\mathrm{AIC}_{\mathrm{c}} \\
\text { Value }\end{array}$ \\
\hline \multirow[t]{7}{*}{ BD } & $x 2$ & $2.34 \times 10^{1}$ & $4.51 \times 10^{0}$ & $2.89 \times 10^{-5 * * *}$ & 0.956 & $2.79 \times 10^{-15}$ & 220 \\
\hline & $x 3$ & $2.09 \times 10^{1}$ & $4.08 \times 10^{0}$ & $3.35 \times 10^{-5 * * *}$ & & & \\
\hline & $\mathrm{x} 4$ & $2.05 \times 10^{1}$ & $4.46 \times 10^{0}$ & $1.26 \times 10^{-4 * * *}$ & & & \\
\hline & $\mathrm{x} 5$ & $9.24 \times 10^{1}$ & $5.59 \times 10^{0}$ & $2.96 \times 10^{-14 * * *}$ & & & \\
\hline & $\mathrm{I}\left(\mathrm{x} 1^{1} \times \mathrm{x} 5^{0.5} /(\mathrm{x} 1+\mathrm{x} 5+0.001)^{0}\right)$ & $-1.04 \times 10^{2}$ & $1.57 \times 10^{1}$ & $9.01 \times 10^{-7 * * *}$ & & & \\
\hline & $\mathrm{I}\left(\mathrm{x} 4^{2.5} \times \times 5^{0.5} /(\mathrm{x} 4+\mathrm{x} 5+0.001)^{0}\right)$ & $-2.04 \times 10^{2}$ & $5.56 \times 10^{1}$ & $1.28 \times 10^{-3 * *}$ & & & \\
\hline & $\mathrm{I}\left(\mathrm{x} 2^{3} \times \mathrm{x} 5^{2.5} /(\mathrm{x} 2+\mathrm{x} 5+0.001)^{3}\right)$ & $-6.49 \times 10^{2}$ & $3.02 \times 10^{2}$ & $4.27 \times 10^{-2 *}$ & & & \\
\hline \multirow[t]{9}{*}{ BTC } & $\mathrm{x} 1$ & $6.24 \times 10^{1}$ & $1.80 \times 10^{1}$ & $2.74 \times 10^{-3 * *}$ & 0.973 & $6.91 \times 10^{-14}$ & 268 \\
\hline & $\mathrm{x} 2$ & $1.24 \times 10^{2}$ & $1.67 \times 10^{1}$ & $6.71 \times 10^{-7 * * *}$ & & & \\
\hline & $\mathrm{x} 3$ & $2.03 \times 10^{2}$ & $1.67 \times 10^{1}$ & $3.97 \times 10^{-10 * * *}$ & & & \\
\hline & $x 4$ & $1.61 \times 10^{2}$ & $1.64 \times 10^{1}$ & $1.13 \times 10^{-8 * * *}$ & & & \\
\hline & $\mathrm{x} 5$ & $1.56 \times 10^{2}$ & $3.08 \times 10^{1}$ & $8.03 \times 10^{-5 * * *}$ & & & \\
\hline & $\mathrm{I}\left(\mathrm{x} 4^{1.5} \times \mathrm{x} 5^{0.5} /(\mathrm{x} 4+\mathrm{x} 5+0.001)^{3}\right)$ & $-1.69 \times 10^{2}$ & $3.20 \times 10^{1}$ & $5.00 \times 10^{-5 * * *}$ & & & \\
\hline & $\mathrm{I}\left(\mathrm{x} 1^{2.5} \times \mathrm{x}^{2.5} \times \mathrm{x}^{2.5}\right)$ & $4.93 \times 10^{5}$ & $9.88 \times 10^{4}$ & $9.63 \times 10^{-5 * * *}$ & & & \\
\hline & $\mathrm{I}\left(\mathrm{x} 2^{2} \times \mathrm{x} 3^{0.5} /(\mathrm{x} 2+\mathrm{x} 3+0.001)^{3}\right)$ & $-1.32 \times 10^{2}$ & $5.16 \times 10^{2}$ & $1.94 \times 10^{-2 *}$ & & & \\
\hline & $\mathrm{I}\left(\mathrm{x} 1^{2} \times \mathrm{x} 4^{0.5} /(\mathrm{x} 1+\mathrm{x} 4+0.001)^{3}\right)$ & $2.33 \times 10^{2}$ & $5.40 \times 10^{1}$ & $4.19 \times 10^{-4 * * *}$ & & & \\
\hline \multirow[t]{5}{*}{ RMF } & $\mathrm{x} 1$ & $6.82 \times 10^{1}$ & $9.94 \times 10^{0}$. & $1.16 \times 10^{-5 * * *}$ & 0.916 & $3.27 \times 10^{-7}$ & 177 \\
\hline & $\mathrm{x} 2$ & $3.54 \times 10^{1}$ & $9.57 \times 10^{0}$ & $2.65 \times 10^{-3 * *}$ & & & \\
\hline & $\mathrm{x} 4$ & $5.79 \times 10^{1}$ & $1.03 \times 10^{1}$ & $8.25 \times 10^{-5 * * *}$ & & & \\
\hline & $\mathrm{I}\left(\mathrm{x} 3^{0.5} \times \mathrm{x} 4^{0.5} /(\mathrm{x} 3+\mathrm{x} 4+0.001)^{0}\right)$ & $-5.21 \times 10^{1}$ & $2.09 \times 10^{1}$ & $2.72 \times 10^{-2} *$ & & & \\
\hline & $\mathrm{I}\left(\mathrm{x} 1^{1.5} \times \times 3^{0.5} /(\mathrm{x} 1+\mathrm{x} 3+0.001)^{0}\right)$ & $1.18 \times 10^{2}$ & $5.00 \times 10^{1}$ & $3.46 \times 10^{-2 *}$ & & & \\
\hline \multirow[t]{7}{*}{ RS } & $\mathrm{x} 1$ & $5.79 \times 10^{-1}$ & $6.97 \times 10^{-2}$ & $4.58 \times 10^{-6 * * *}$ & 0.967 & $2.82 \times 10^{-8}$ & -11 \\
\hline & $\mathrm{x} 2$ & $4.75 \times 10^{-1}$ & $1.43 \times 10^{-1}$ & $6.65 \times 10^{-3} * *$ & & & \\
\hline & $\mathrm{x} 4$ & $1.60 \times 10^{-1}$ & $6.90 \times 10^{-2}$ & $4.11 \times 10^{-2 *}$ & & & \\
\hline & $\mathrm{I}\left(\mathrm{x} 1^{1.5} \times \mathrm{x} 4^{0.5} /(\mathrm{x} 1+\mathrm{x} 4+0.001)^{3}\right)$ & $6.13 \times 10^{-1}$ & $1.12 \times 10^{-1}$ & $1.88 \times 10^{-4 * * *}$ & & & \\
\hline & $\mathrm{I}\left(\mathrm{x} 1^{3} \times \mathrm{x}^{3} /(\mathrm{x} 1+\mathrm{x} 3+0.001)^{0}\right)$ & $1.99 \times 10^{1}$ & $6.14 \times 10^{0}$ & $7.77 \times 10^{-3 * *}$ & & & \\
\hline & $\mathrm{I}\left(\mathrm{x} 1^{0.5} \times \mathrm{x} 2^{0.5} /(\mathrm{x} 1+\mathrm{x} 2+0.001)^{3}\right)$ & $-1.07 \times 10^{-1}$ & $3.12 \times 10^{-2}$ & $5.82 \times 10^{-3 * *}$ & & & \\
\hline & $\mathrm{I}\left(\mathrm{x} 2^{3} \times x 5^{3} /(\mathrm{x} 2+\mathrm{x} 5+0.001)^{0}\right)$ & $2.06 \times 10^{2}$ & $7.36 \times 10^{1}$ & $1.72 \times 10^{-2 *}$ & & & \\
\hline \multirow[t]{8}{*}{ TTI } & $x 3$ & $3.66 \times 10^{1}$ & $4.57 \times 10^{0}$ & $1.66 \times 10^{-7 * * *}$ & 0.833 & $5.05 \times 10^{-7}$ & 208 \\
\hline & $\mathrm{x} 5$ & $2.40 \times 10^{1}$ & $4.15 \times 10^{0}$ & $1.46 \times 10^{-5 * * *}$ & & & \\
\hline & $\mathrm{I}\left(\mathrm{x} 1^{0.5} \times \mathrm{x} 5^{0.5} /(\mathrm{x} 1+\mathrm{x} 5+0.001)^{0}\right)$ & $-2.79 \times 10^{1}$ & $7.35 \times 10^{0}$ & $1.22 \times 10^{-3 * *}$ & & & \\
\hline & $\mathrm{I}\left(\mathrm{x} 2^{3} \times x 5^{3} /(\mathrm{x} 2+\mathrm{x} 5+0.001)^{0}\right)$ & $5.59 \times 10^{3}$ & $2.36 \times 10^{3}$ & $2.87 \times 10^{-2 *}$ & & & \\
\hline & $\mathrm{I}\left(\mathrm{x}^{3} \times \mathrm{x}^{2} /(\mathrm{x} 1+\mathrm{x} 3+0.001)^{3}\right)$ & $-5.72 \times 10^{2}$ & $1.57 \times 10^{2}$ & $1.73 \times 10^{-3} * *$ & & & \\
\hline & $\mathrm{I}\left(\mathrm{x} 3^{2.5} \times \mathrm{x} 4^{0.5} /(\mathrm{x} 3+\mathrm{x} 4+0.001)^{0}\right)$ & $-1.35 \times 10^{2}$ & $4.34 \times 10^{1}$ & $5.93 \times 10^{-3 * *}$ & & & \\
\hline & $\mathrm{I}\left(\mathrm{x} 3^{3} \times x 5^{3} /(\mathrm{x} 3+\mathrm{x} 5+0.001)^{0}\right)$ & $-1.10 \times 10^{3}$ & $3.67 \times 10^{2}$ & $7.21 \times 10^{-3 * *}$ & & & \\
\hline & $\mathrm{I}\left(\mathrm{x}^{3} \times \mathrm{x} 3^{3} /(\mathrm{x} 2+\mathrm{x} 3+0.001)^{0}\right)$ & $-9.45 \times 10^{2}$ & $3.62 \times 10^{2}$ & $1.72 \times 10^{-2} *$ & & & \\
\hline \multirow[t]{8}{*}{ VC } & $\mathrm{x} 1$ & $1.42 \times 10^{-3}$ & $2.17 \times 10^{-4}$ & $2.74 \times 10^{-5 * * *}$ & 0.967 & $4.80 \times 10^{-9}$ & -250 \\
\hline & $\mathrm{x} 2$ & $6.75 \times 10^{-4}$ & $2.18 \times 10^{-4}$ & $9.14 \times 10^{-3 * *}$ & & & \\
\hline & $\mathrm{x} 3$ & $7.04 \times 10^{-4}$ & $2.14 \times 10^{-4}$ & $6.40 \times 10^{-3 * *}$ & & & \\
\hline & $x 4$ & $1.16 \times 10^{-3}$ & $1.83 \times 10^{-4}$ & $3.77 \times 10^{-5 * * *}$ & & & \\
\hline & $x 5$ & $1.56 \times 10^{-3}$ & $3.68 \times 10^{-4}$ & $1.14 \times 10^{-3 * *}$ & & & \\
\hline & $\mathrm{I}\left(\mathrm{x} 1^{1.5} \times \mathrm{x} 3^{0.5} /(\mathrm{x} 1+\mathrm{x} 3+0.001)^{0}\right)$ & $3.91 \times 10^{-3}$ & $1.05 \times 10^{-3}$ & $2.89 \times 10^{-3 * *}$ & & & \\
\hline & $\mathrm{I}\left(\mathrm{x} 1^{3} \times \mathrm{x} 2^{2.5} /(\mathrm{x} 1+\mathrm{x} 2+0.001)^{2}\right)$ & $3.68 \times 10^{-2}$ & $1.30 \times 10^{-2}$ & $1.55 \times 10^{-2} *$ & & & \\
\hline & $\mathrm{I}\left(\mathrm{x}^{3} \times \mathrm{x} 5^{3} /(\mathrm{x} 3+\mathrm{x} 5+0.001)^{0}\right)$ & $-5.24 \times 10^{-1}$ & $2.10 \times 10^{-1}$ & $2.81 \times 10^{-2 *}$ & & & \\
\hline \multirow[t]{7}{*}{ VFH } & $x 1$ & $4.31 \times 10^{-1}$ & $3.32 \times 10^{-2}$ & $1.71 \times 10^{-11 * * *}$ & 0.962 & $1.50 \times 10^{-14}$ & -79 \\
\hline & $\mathrm{x} 2$ & $8.99 \times 10^{-2}$ & $3.07 \times 10^{-2}$ & $8.05 \times 10^{-3 * *}$ & & & \\
\hline & $\mathrm{x} 3$ & $1.54 \times 10^{-1}$ & $3.10 \times 10^{-2}$ & $6.76 \times 10^{-5 * * *}$ & & & \\
\hline & $x 4$ & $1.69 \times 10^{-1}$ & $3.32 \times 10^{-2}$ & $4.78 \times 10^{-5 * * *}$ & & & \\
\hline & $\mathrm{x} 5$ & $1.05 \times 10^{-1}$ & $3.27 \times 10^{-2}$ & $4.10 \times 10^{-3} * *$ & & & \\
\hline & $\mathrm{I}\left(\mathrm{x} 1^{3} \times \mathrm{x} 4^{3} /(\mathrm{x} 1+\mathrm{x} 4+0.001)^{0}\right)$ & $-3.87 \times 10^{2}$ & $1.60 \times 10^{2}$ & $2.44 \times 10^{-2 *}$ & & & \\
\hline & $\mathrm{I}\left(\mathrm{x} 1^{3} \times \mathrm{x} 4^{2.5} /(\mathrm{x} 1+\mathrm{x} 4+0.001)^{0}\right)$ & $2.71 \times 10^{2}$ & $1.14 \times 10^{2}$ & $2.70 \times 10^{-2} *$ & & & \\
\hline \multirow[t]{10}{*}{ DVF } & $\mathrm{x} 1$ & $7.14 \times 10^{1}$ & $1.83 \times 10^{1}$ & $1.12 \times 10^{-3 * *}$ & 0.972 & $6.44 \times 10^{-13}$ & 272 \\
\hline & $x 2$ & $1.12 \times 10^{2}$ & $1.57 \times 10^{1}$ & $1.78 \times 10^{-6 * * *}$ & & & \\
\hline & $\mathrm{x} 3$ & $1.72 \times 10^{2}$ & $1.57 \times 10^{1}$ & $4.12 \times 10^{-9 * * *}$ & & & \\
\hline & $x 4$ & $1.68 \times 10^{2}$ & $1.70 \times 10^{1}$ & $1.79 \times 10^{-8 * * *}$ & & & \\
\hline & $\mathrm{x} 5$ & $1.68 \times 10^{2}$ & $3.13 \times 10^{1}$ & $5.36 \times 10^{-5 * * *}$ & & & \\
\hline & $\mathrm{I}\left(\mathrm{x} 4^{1.5} \times \mathrm{x} 5^{0.5} /(\mathrm{x} 4+\mathrm{x} 5+0.001)^{3}\right)$ & $-2.24 \times 10^{2}$ & $3.29 \times 10^{1}$ & $3.12 \times 10^{-6 * * *}$ & & & \\
\hline & $\mathrm{I}\left(\mathrm{x} 1^{2.5} \times \mathrm{x} 2^{2.5} \times \times 3^{2.5}\right)$ & $1.06 \times 10^{7}$ & $3.82 \times 10^{6}$ & $1.28 \times 10^{-2} *$ & & & \\
\hline & $\mathrm{I}\left(\mathrm{x} 1^{2} \times \mathrm{x} 4^{0.5} /(\mathrm{x} 1+\mathrm{x} 4+0.001)^{3}\right)$ & $3.12 \times 10^{2}$ & $5.95 \times 10^{1}$ & $6.59 \times 10^{-5 * * *}$ & & & \\
\hline & $\mathrm{I}\left(\mathrm{x} 1^{2.5} \times \mathrm{x} 2^{2.5} \times x 3^{2}\right)$ & $-5.89 \times 10^{6}$ & $2.20 \times 10^{6}$ & $1.59 \times 10^{-2} *$ & & & \\
\hline & $\mathrm{I}\left(\mathrm{x} 1^{3} \times \mathrm{x} 4^{3} /(\mathrm{x} 1+\mathrm{x} 4+0.001)^{0}\right)$ & $-3.83 \times 10^{3}$ & $1.72 \times 10^{3}$ & $3.95 \times 10^{-2 *}$ & & & \\
\hline
\end{tabular}




\subsection{Optimisation}

The optimisation results demonstrated a good fit of the data within the response surface (Tables 8 and 9). For most flammability metrics, the global and local solvers found optimum values and hence mixtures that corresponded with the actual mixtures that produced maxima and minima values (Tables 4 and 5). In some cases, there was more than one optimal solution with the SCD because none of the flammability metrics can be less than zero within these complex response surfaces. The optimization did not appear to perform well when identifying the minima for VC, BTC and RS for Halls Creek, and VC for Rofe Park. However, the actual mixtures for these metrics all had values of zero, whereas the mixture selected by the optimisation routine was the smallest non-zero value.

Table 8. Optimisation of the ideal mixture for (a) maximum and (b) minimum flammability for litter from Halls Creek for bulk density (BD), burn to completion (BTC), duration of visual flaming (DVF), residual mass fraction (RMF), rate of spread (RS), time-to-ignition (TTI), volume consumed (VC), and vertical flame height (VFH). Values represent the proportion of each litter component within a mixture. Key to flammability mixtures for litter from Halls Creek $(\mathrm{H})$ : other $(\mathrm{O})$, twigs $(\mathrm{T})$, leaves $(\mathrm{L})$, decomposed material (D). ${ }^{1}$ Only if the mixture ignited.

\begin{tabular}{|c|c|c|c|c|c|c|}
\hline Metric & $\begin{array}{l}\text { Other } \\
(x 1)\end{array}$ & $\begin{array}{l}\text { Twigs } \\
(\mathrm{x} 2)\end{array}$ & $\begin{array}{l}\text { Leaves } \\
(\mathrm{x} 3)\end{array}$ & $\begin{array}{l}\text { Decomposed } \\
\text { material }(x 4)\end{array}$ & $\begin{array}{l}\text { Corresponding } \\
\text { sample ID for } \\
\text { optimum mixture }\end{array}$ & $\begin{array}{l}\text { Sample ID for maximum } \\
\text { measured value }\end{array}$ \\
\hline BD & - & 1 & - & - & HT & HT \\
\hline BTC & - & 0.5 & 0.5 & - & HTL & HTL \\
\hline DVF & - & 0.5 & 0.5 & - & HTL & HTL \\
\hline RMF & - & - & 1 & - & HL & HL \\
\hline RS & 0.5 & 0.5 & - & - & НОТ & HOT \\
\hline TTI & - & 1 & - & - & HT & HT \\
\hline VC & - & - & 1 & - & $\mathrm{HL}$ & $\mathrm{HL}$ \\
\hline VFH & - & - & 1 & - & HL & HL \\
\hline \multicolumn{7}{|l|}{ (b) } \\
\hline Metric & $\mathbf{x 1}$ & $\mathbf{x} 2$ & $x 3$ & $x 4$ & $\begin{array}{l}\text { Corresponding } \\
\text { sample ID for } \\
\text { optimum mixture }\end{array}$ & $\begin{array}{l}\text { Sample ID for minimum } \\
\text { measured value }{ }^{1}\end{array}$ \\
\hline BD & - & - & 1 & - & HL & $\mathrm{HL}$ \\
\hline BTC & 0.5 & - & - & 0.5 & HOD & HOLD, HTLD \\
\hline DVF & 0.5 & - & - & 0.5 & HOD & HOD, HOLD, HTLD \\
\hline RMF & 0.5 & 0.5 & - & - & HOT & HOT \\
\hline RS & - & 0.5 & 0.5 & - & HTL & $\begin{array}{l}\text { HT, HOD, HTD, HLD, } \\
\text { HOTL, HOTD, HOLD, } \\
\text { HTLD }\end{array}$ \\
\hline TTI & $\begin{array}{c}0.5 \\
0.25\end{array}$ & - & $\begin{array}{c}0.5 \\
0.25\end{array}$ & - & $\begin{array}{c}\text { HOL } \\
\text { HOTLD }\end{array}$ & HOL, HOTLD \\
\hline vC & 1 & - & - & - & $\mathrm{HO}$ & $\begin{array}{l}\text { HT, HOD, HTD, HLD, } \\
\text { HOTL, HOTD, HOLD, } \\
\text { HTLD, HOTLD }\end{array}$ \\
\hline \multirow[t]{3}{*}{ VFH } & 0.5 & - & - & 0.5 & HOD & HOD, HTD, HOLD, HTLD \\
\hline & - & 0.5 & - & 0.5 & HTD & \\
\hline & $1 / 3$ & - & $1 / 3$ & $1 / 3$ & HOLD & \\
\hline
\end{tabular}


Table 9. Optimisation of the ideal mixture for (a) maximum and (b) minimum flammability for litter from Rofe Park for bulk density (BD), burn to completion (BTC), duration of visual flaming (DVF), residual mass fraction (RMF), rate of spread (RS), time-to-ignition (TTI), volume consumed (VC), and vertical flame height (VFH). Values represent the proportion of each litter component within a mixture. Key to flammability mixtures for litter from Rofe Park (R): Allocasuarina littoralis cladodes (C), other (O), twigs (T), leaves (L), decomposed material (D). ${ }^{1}$ Only if the mixture ignited.

\begin{tabular}{|c|c|c|c|c|c|c|c|}
\hline (a) & & & & & & & \\
\hline Metric & $\begin{array}{l}\text { Cladodes } \\
\text { (x1) }\end{array}$ & $\begin{array}{l}\text { Other } \\
(\mathrm{x} 2)\end{array}$ & $\begin{array}{l}\text { Twigs } \\
\text { (x3) }\end{array}$ & $\begin{array}{l}\text { Leaves } \\
(\mathrm{x} 4)\end{array}$ & $\begin{array}{l}\text { Decomposed } \\
\text { Material (x5) }\end{array}$ & $\begin{array}{l}\text { Corresponding } \\
\text { Sample ID for } \\
\text { Optimum Mixture }\end{array}$ & $\begin{array}{c}\text { Sample ID for } \\
\text { Maximum Measured } \\
\text { Value }\end{array}$ \\
\hline BD & - & - & - & - & 1 & $\mathrm{RD}$ & RD \\
\hline BTC & $1 / 3$ & $1 / 3$ & $1 / 3$ & - & - & RCOT & RCOT \\
\hline DVF & $1 / 3$ & $1 / 3$ & $1 / 3$ & - & - & RCOT & RCOT \\
\hline RMF & $1 / 3$ & $1 / 3$ & - & $1 / 3$ & - & $\mathrm{RCOL}$ & RCOL \\
\hline RS & 0.25 & - & 0.25 & 0.25 & 0.25 & RCTLD & RCTLD \\
\hline TTI & - & $1 / 3$ & $1 / 3$ & - & $1 / 3$ & ROTD & ROTD \\
\hline VC & $1 / 3$ & - & $1 / 3$ & $1 / 3$ & - & RCTL & RCTL \\
\hline VFH & $1 / 3$ & - & $1 / 3$ & $1 / 3$ & - & RCTL & RCTL \\
\hline \multicolumn{8}{|l|}{ (b) } \\
\hline Metric & $\mathbf{x 1}$ & $\mathrm{x} 2$ & $\mathrm{x} 3$ & $x 4$ & x5 & $\begin{array}{l}\text { Corresponding } \\
\text { Sample ID for } \\
\text { Optimum Mixture }\end{array}$ & $\begin{array}{c}\text { Sample ID for } \\
\text { Minimum Measured }^{\text {Value }}{ }^{1} \\
\end{array}$ \\
\hline BD & $1 / 3$ & - & $1 / 3$ & $1 / 3$ & - & RCTL & RCTL \\
\hline BTC & - & 0.25 & 0.25 & 0.25 & 0.25 & ROTD & RD, RTD, ROTD \\
\hline DVF & - & 0.25 & 0.25 & 0.25 & 0.25 & ROTD & RD, RTD, ROTD \\
\hline RMF & - & - & 1 & - & - & RT & RT \\
\hline RS & - & - & 1 & - & - & RT & RT \\
\hline \multirow[t]{5}{*}{ TTI } & 0.5 & 0.5 & - & - & - & $\mathrm{RCO}$ & $\mathrm{RCO}$ \\
\hline & 0.5 & - & - & - & 0.5 & $\mathrm{RCD}$ & $\mathrm{RCD}$ \\
\hline & $1 / 3$ & $1 / 3$ & $1 / 3$ & - & - & RCOT & RCOT \\
\hline & $1 / 3$ & $1 / 3$ & - & $1 / 3$ & - & RCOL & RCOL \\
\hline & $1 / 3$ & - & - & $1 / 3$ & $1 / 3$ & RCLD & RCLD \\
\hline VC & - & - & 1 & - & - & RT & $\begin{array}{c}\text { RD, ROT, ROL, RTD, } \\
\text { RLD, ROTD, ROLD, } \\
\text { RTLD, RCOTD, } \\
\text { ROTLD }\end{array}$ \\
\hline VFH & - & 1 & - & - & - & $\mathrm{RO}$ & $\mathrm{RO}$ \\
\hline
\end{tabular}

\section{Discussion}

Land managers require information about fuel loads and flammability to guide them in mitigating risk from bushfires. Having information about flammability metrics such as TTI, RS and VFH will assist them in prioritising where and when to conduct prescribed burns. If a vegetation type that is known to be highly flammable in terms of positive, non-additive effects on litter, has a high fuel load, and is near strategic assets, then this information will be useful for planning. As such, knowledge of the physical and chemical properties of litter is important to document and can be used for the interpretation of the capacity of forests and woodlands to burn, but provides limited ability to predict or understand fuel flammability. Our study sites were chosen as being representative of long unburnt Sydney Coastal Dry Sclerophyll Forest [21] and when assessed on the basis of a fuel hazard score [17] both had similar characteristics (e.g., completely connected litter, similar vertical structure and tree density) and, consequently, a similar fire risk (i.e., extreme). However, flammability measurements demonstrated considerable differences between these sites. For example, nearly twice as many litter mixtures from Rofe Park ignited compared to Halls Creek and the rate of spread in those mixtures was on average twice as fast. The presence of cladodes in litter mixtures from Rofe Park had a non-additive effect for several flammability metrics, potentially making this site more flammable overall and a greater risk to assets on the urban-bush interface. This highlights the importance for land managers 
to have a broader range of data or predictive tools available to them to inform their choices when it comes to prioritising areas for hazard reduction burning.

An advantage of the SCD mixture design used in this study is that it enabled a wide composition mix to be used, which arguably is more representative of litter than could be captured by random sampling. In addition, decomposed material, twigs, leaves, woody fruits and bark can be found in surface litter in most forests, so this experimental method can be applied to other forest types regardless of the dominant tree species. Previous studies have determined the existence of non-additive effects on flammability by using the weighted mean of single species measurements or the sum of the effects of each component species in a monospecific fuel as a null expectation, and any measured value that was different to this null measurement was considered to be a non-additive effect $[10,11]$. To our knowledge, this study represents the first time a GBM has been used to determine the best statistical model fit for a range of flammability metrics, along with the use of optimisation processes to identify mixtures where the measure being examined may be at its lowest or highest value. An advantage of using GBM over other approaches is that it generates non-linear equations containing terms describing responses for individual components as well as terms describing their interaction [20]. Hence, it is possible to identify both positive and negative effects that components have upon a flammability metric, as well as the relative strength that fuel components or interactions have, and use this to make predictions.

The flammability of vegetation mixtures has been examined previously $[10-12,37,38]$ and non-additive effects of vegetation on flammability have been identified, even though different experimental methodologies were used. This study was consistent with those findings. The approach taken by other studies investigating flammability [10-12,37,38] separated litter and leaves according to plant species. By contrast, litter used in this study was arranged according to functional components (e.g., twigs and leaves), which may have originally been from several species, and only one litter component, A. littoralis, was specifically isolated because of its abundance. This makes direct comparison among studies, beyond their major findings, difficult, because all have used different methodologies and even units of measurement. This general problem has been reviewed in [39]. Cornelissen et al. [40] made some attempt to standardise the assessment of flammability according to plant functional traits, but many of the empirical measurements of flammability that are useful for predictive modelling were relegated to "extra" information. Hence, there needs to be consensus as to the type of measurements made in order to make faithful comparisons among studies.

There were individual litter components that had a significant positive effect on flammability metrics in litter mixtures, but they were not the same components for both sites. For example, for Halls Creek, twigs positively affected TTI and the other fraction and leaves both positively affected VFH (see Table 4 for other examples). By contrast, there were a number of individual components in litter from Rofe Park that had a very strong positive effect, the most common being cladodes affecting RS, VFH, RMF and VC (Table 5). Cladodes from A. littoralis was a component that individually had a very strong positive effect, strong interactions, and non-additive effects on BTC, RS, VC, VFH and DVF. Leaf shape and size has been found to be important for accounting for flammability in general [40], and, more specifically, non-additive flammability effects of mixtures [10,11]. In this study, cladodes were from A. littoralis, being long and thin and are similar in shape to pine needles. Pinus lambertiana, P. jeffreyii and P. ponderosa have been shown to produce non-additive effects in litter mixtures [11] and have the greatest flame heights and rate of spread [11], as did cladodes in this study. Indeed, other studies have also demonstrated that leaves with similar shape ignite rapidly, burn quickly and are hotter with greater flame heights [41,42]. It follows that other vegetation types with any species of Casuarina and Allocasuarina, of which there are close to 100 species in the family [43], as a common component in the overstorey or midstorey might require special attention from land managers. Leaves from gums or eucalypts (i.e., species in the genera Eucalyptus, Angophora, Corymbia), which were prevalent in the overstorey and midstorey at the two study sites, are of a different shape and thickness (i.e., longer and thicker) than leaves from the species studied elsewhere for flammability [10,11]. This could at least partially explain differences in other flammability metrics that have been reported here. 
The use of the SCD design and the production of equations by the GBM enable us to identify fuel mixtures where the flammability may potentially be at the highest or lowest. Maximum values of the flammability measures were driven by twigs and leaves at Halls Creek and by mixtures of twigs for Rofe Park, while the minimum values were driven by decomposition litter at Halls Creek and other and cladodes at Rofe Park. This, again, highlights the differences between the sites. However, along with the goodness-of-fit statistics for the GBM model (e.g., high adjusted $\mathrm{R}^{2}$ values, low AICc values), comparison of the identity of these predicted mixtures against the mixtures that actually produced the maximum or minimum values shows that these models appear to be working well in most cases. In the situations where the optimisations did not appear to match successfully, the optimisation routine was selecting the mixture with the closest non-zero value. This may simply be a consequence of zero being a boundary condition in the optimisation routine. A proper validation of these models would occur by testing their performance against an independent dataset. This is one of several caveats that need to be considered when applying the model results. These models were developed under a set of identical, controlled conditions where the condition of the fuel (i.e., moisture content) was made constant and was collected at only one time of the year. However, seasonality in the litter composition, which will affect flammability, is intrinsic to the experimental design (i.e., changes in the composition of the litter throughout the year are captured by our use of many, wide-ranging mixtures). Furthermore, the Halls Creek and Rofe Park sites were in steep forested terrain and none of the variables associated with this setting, such as wind, slope, or meteorological factors such as relative humidity and precipitation that affect ground wetness, aspect and topography [44] were included in the experimental design. Indeed, all of these features will affect litter flammability in the field. However, the SCD design can accommodate the adding of different levels of features such as moisture content [29]. Thus, it is plausible that future experiments can examine these variables in conjunction with changes in mixtures and potentially improve model accuracy.

\section{Conclusions}

We investigated the fuel structure, fire risk and flammability of two sites around Sydney, Australia, that were both classified as Sydney Coastal Dry Sclerophyll Forest. Although both sites had similar fuel structures and associated assessments of fire risk, the flammability of the litter layers was markedly different because of the presence of Allocasuarina littoralis cladodes. Using a simplex complex design approach with a general blending model [20], it was possible to model several flammability metrics, with and without the presence of cladodes, and identify potential mixtures of litter that would lead to enhanced or decreased flammability. The methodology used in this study is not restricted to Sydney Coastal Dry Sclerophyll Forest and can be readily applied to other vegetation types. Furthermore, the models generated only require the mixture composition of the litter in order to make a prediction for a flammability metric. Thus, information to describe the patterns and mechanisms of flammability across a vegetation class could be calculated based upon existing fuel load mapping. This would readily provide land managers with further information to inform decisions around planning and prioritising fire mitigation treatments.

Author Contributions: Conceptualization, M.P. and T.L.B.; methodology, M.P. and T.L.B.; formal analysis, A.G.G.; investigation, A.G.G., M.P. and T.L.B.; resources, M.P. and T.L.B.; data curation, A.G.G.; writing-original draft preparation, A.G.G.; writing—review and editing, A.G.G., M.P. and T.L.B.; visualisation, A.G.G.; supervision, M.P. and T.L.B.; project administration, T.L.B. and M.P. All authors have read and agreed to the published version of the manuscript.

Funding: This research was funded by the University of Sydney and the Bushfire and Natural Hazards Cooperative Research Centre.

Acknowledgments: The authors would like to acknowledge the assistance of Amelia Jones and Michelle Brown (Hornsby Shire Council, NSW, Australia) with help in identifying and accessing sample sites, and field data collection. We also thank Veronica Quintanilla Berjon (University of Sydney) for assistance with the burning experiments.

Conflicts of Interest: The authors declare no conflict of interest. 


\section{Appendix A}

Table A1. Flammability components, their definitions and examples of fire test measurements, time to ignition (TTI), vertical fuel height (VFH), rate of spread (RS), burn to completion (BTC), residual mass fraction (RMF), volume consumed (VC), duration of visual flaming (DVF). (Source: adapted from White and Zipperer [39]).

\begin{tabular}{cccc}
\hline Components & Definition & Potential Test Response & Metric \\
\hline \multirow{2}{*}{ Ignitability } & $\begin{array}{c}\text { Time until ignition once } \\
\text { exposed to a heat source }\end{array}$ & $\begin{array}{c}\text { Ignition time }(\mathrm{s}) \\
\text { Fuel ignited }(\mathrm{Y} / \mathrm{N})\end{array}$ & TTI \\
\hline \multirow{2}{*}{ Combustability } & $\begin{array}{c}\text { Rapidity of combustion } \\
\text { after ignition }\end{array}$ & $\begin{array}{c}\text { Visual flame height }(\mathrm{m}) \\
\text { Rate of spread }\left(\mathrm{m} \mathrm{s}^{-1}\right)\end{array}$ & $\begin{array}{c}\text { VFH } \\
\text { RS }\end{array}$ \\
\hline \multirow{2}{*}{ Consumability } & $\begin{array}{c}\text { Proportion of mass or } \\
\text { volume consumed by } \\
\text { combustion }\end{array}$ & $\begin{array}{c}\text { Fuel mass }(\%) \text { after burning, Mass loss rate } \\
\text { Fuel burn to edge }\left(\mathrm{Y} / \mathrm{N}^{2}\right)\end{array}$ & BTC \\
& RMF \\
Sustainability & Ability to sustain & Area or volume consumed $\left(\mathrm{m}^{2}, \mathrm{~m}^{3}\right)$ & VC \\
\hline
\end{tabular}

\section{References}

1. McAneney, J.; Sandercock, B.; Crompton, R.; Mortlock, T.; Musulin, R.; Pielke, R., Jr.; Gissing, A. Normalised insurance losses from Australian natural disasters: 1966-2017. Environ. Hazards 2019, 18, 414-433. [CrossRef]

2. Handmer, J.; Ladds, M.; Magee, L. Updating the costs of disasters in Australia. Aust. J. Emerg. Manag. 2018, $33,40-46$.

3. Australasian Fire and Emergency Service Authorities Council; Australasian Fire and Emergency Service Authorities Council Limited. Analysis of tools and methodologies to balance competing objectives of burning programs. In Prescribed Burning Objectives: Cost-Benefit Analysis; Australasian Fire and Emergency Service Authorities Council Limited: Melbourne, Australia, 2018; p. 79.

4. Reserve Bank of Australia (RBA) Historical Data for Exchange Rates-Daily-2018 to Current. Available online: https://www.rba.gov.au/statistics/historical-data.html\#exchange-rates (accessed on 10 April 2020).

5. Victorian Bushfires Royal Commission; Teague, B. 2009 Victorian Bushfires Royal Commission; Government Printer for the State of Victoria: Melbourne, Australia, 2010.

6. Commonwealth. Parliamentary Debates. House of Representatives Official Hansard, 4 February 2020; 1.

7. Chung, W. Optimizing fuel treatments to reduce wildland fire risk. Curr. For. Rep. 2015, 1, 44-51. [CrossRef]

8. Schwilk, D.W. Dimensions of plant flammability. New Phytol. 2015, 206, 486-488. [CrossRef] [PubMed]

9. Fernandes, P.M.; Cruz, M.G. Plant flammability experiments offer limited insight into vegetation-fire dynamics interactions. New Phytol. 2012, 194, 606-609. [CrossRef] [PubMed]

10. Della Rocca, G.; Danti, R.; Hernando, C.; Guijarro, M.; Madrigal, J. Flammability of two Mediterranean mixed forests: Study of the non-additive effect of fuel mixtures in laboratory. Front. Plant Sci. 2018, 9, 825. [CrossRef]

11. de Magalhães, R.M.; Schwilk, D.W. Leaf traits and litter flammability: Evidence for non-additive mixture effects in a temperate forest. J. Ecol. 2012, 100, 1153-1163. [CrossRef]

12. van Altena, C.; van Logtestijn, R.; Cornwell, W.; Cornelissen, H. Species composition and fire: Non-additive mixture effects on ground fuel flammability. Front. Plant Sci. 2012, 3, 1-10.

13. Candioti, L.V.; De Zan, M.M.; Cámara, M.S.; Goicoechea, H.C. Experimental design and multiple response optimization. Using the desirability function in analytical methods development. Talanta 2014, 124, $123-138$. [CrossRef]

14. Gill, A.M.; Zylstra, P. Flammability of Australian forests. Aust. For. 2005, 68, 87-93. [CrossRef]

15. Varner, J.M.; Kane, J.M.; Kreye, J.K.; Engber, E. The flammability of forest and woodland litter: A synthesis. Curr. For. Rep. 2015, 1, 91-99. [CrossRef]

16. Leardi, R. Experimental design in chemistry: A tutorial. Anal. Chim. Acta 2009, 652, 161-162. [CrossRef] [PubMed] 
17. Gould, J.S.; McCaw, W.L.; Cheney, N.P. Quantifying fine fuel dynamics and structure in dry eucalypt forest (Eucalyptus marginata) in Western Australia for fire management. For. Ecol. Manag. 2011, 262, 531-546. [CrossRef]

18. Anderson, H.E. Forest fuel ignitability. Fire Technol. 1970, 6, 312-319. [CrossRef]

19. Martin, R.E.; Gordon, D.A.; Gutierrez, M.A. Assessing the flammability of domestic and wildland vegetation. In Proceedings of the 12th Conference on Fire and Forest Meteorology, Jekyll Island, GA, USA, 26-28 October 1993; p. 796.

20. Brown, L.; Donev, A.N.; Bissett, A.C. General blending models for data from mixture experiments. Technometrics 2015, 57, 449-456. [CrossRef]

21. Keith, D.A. Ocean Shores to Desert Dunes: The Native Vegetation of NSW and the ACT; Department of Environment and Conservation (NSW): Hurstville, Australia, 2004; pp. 1-353.

22. Hornsby Shire Council. A Snapshot of the Hornsby Shire; Hornsby Shire Council: Hornsby, Australia, 2016; p. 69.

23. Australian Government, Bureau of Meteorology. Climate Data Online. Available online: http://www.bom. gov.au/climate/data/index.shtml (accessed on 12 September 2018).

24. Brown, M.; Hornsby Shire Council, Sydney, Australia; Jones, A.; Hornsby Shire Council, Sydney, Australia. Personal communication. 2016.

25. Cottam, G.; Curtis, J.T. The use of distance measures in phytosociological sampling. Ecology 1956, 37, 451-460. [CrossRef]

26. ASTM. American Society for Testing and Materials International Standard; ASTM E1755-01; ASTM: West Conshohocken, PA, USA, 2015.

27. Lawson, J.; Willden, C.; Piepel, G. mixexp: Design and Analysis of Mixture Experiments. R Package Version 1.2.5. 2016. Available online: ftp://ftp.uvigo.es/CRAN/web/packages/mixexp/mixexp.pdf (accessed on 25 September 2018).

28. R Core Team. R: A Language and Environment for Statistical Computing; R Version 3.4.1; R Foundation for Statistical Computing: Vienna, Austria, 2017; Available online: https://www.R-project.org/ (accessed on 25 September 2018).

29. Cornell, J.A. Experiments with Mixtures-Designs, Models, and the Analysis of Mixture Data; John Wiley \& Sons: New York, NY, USA, 2002; pp. 1-649.

30. Lawson, J.; Willden, C. Mixture experiments in R using mixexp. J. Stat. Softw. 2016, 72, 1-20. [CrossRef]

31. Plucinski, M.P.; Anderson, W.R. Laboratory determination of factors influencing successful point ignition in the litter layer of shrubland vegetation. Int. J. Wildland Fire 2008, 17, 628-637. [CrossRef]

32. Mazerolle, M.J. AICcmodavg: Model Selection and Multimodal Inference Based on (Q)AIC(c). R Package Version 2.1-1. 2017. Available online: https://cran.r-project.org/web/packages/AICcmodavg/AICcmodavg.pdf (accessed on 25 September 2018).

33. Johnson, S.G. The NLopt Nonlinear-Optimization Package. R Package Version 1.0.4. 2017. Available online: https://cran.r-project.org/web/packages/nloptr/index.html (accessed on 11 May 2020).

34. Powell, M.J.D. A direct search optimization method that models the objective and constraint functions by linear interpolation. In Advances in Optimization and Numerical Analysis; Springer: Dordrecht, The Netherlands, 1994; pp. 51-67.

35. Conn, A.R.; Gould, N.I.; Toint, P.L. A globally convergent augmented Lagrangian algorithm for optimization with general constraints and simple bounds. SIAM J. Numer. Anal. 1991, 28, 545-572. [CrossRef]

36. Birgin, E.G.; Martinez, J.M. Improving ultimate convergence of an augmented Lagrangian method. Optim. Methods Softw. 2008, 23, 177-195. [CrossRef]

37. Blauw, L.G.; Wensink, N.; Bakker, L.; van Logtestijn, R.S.P.; Aerts, R.; Nadejda, A.; Soudzilovskaia, N.A.; Cornelissen, J.H.C. Fuel moisture content enhances nonadditive effects of plant mixtures on flammability and fire behavior. Ecol. Evolut. 2015, 5, 3830-3841. [CrossRef]

38. Zhao, W.; Cornwell, W.K.; van Pomeren, M.; van Logtestijn, R.S.P.; Cornelissen, J.H.C. Species mixture effects on flammability across plant phylogeny: The importance of litter particle size and the special role for non-Pinus Pinaceae. Ecol. Evolut. 2016, 6, 8223-8234. [CrossRef] [PubMed]

39. White, R.H.; Zipperer, W.C. Testing and classification of individual plants for fire behaviour: Plant selection for the wildland-urban interface. Int. J. Wildland Fire 2010, 19, 213-227. [CrossRef] 
40. Cornelissen, J.H.C.; Lavorel, S.; Garnier, E.; Diaz, S.; Buchmann, N.; Gurvich, D.E.; Reich, P.B.; Ter Steege, H.; Morgan, H.D.; Van Der Heijden, M.G.A.; et al. A handbook of protocols for standardised and easy measurement of plant functional traits worldwide. Aust. J. Bot. 2003, 51, 335-380. [CrossRef]

41. Scarff, F.R.; Westoby, M. Leaf litter flammability in some semi-arid Australian woodlands. Funct. Ecol. 2006, 20, 745-752. [CrossRef]

42. Kane, J.M.; Varner, J.M.; Hiers, J.K. The burning characteristics of southeastern oaks: Discriminating fire facilitators from fire impeders. For. Ecol. Manag. 2008, 256, 2039-2045. [CrossRef]

43. Johnson, L.A.S.; Wilson, K.L. Casuarinaceae. In Flowering Plants Dicotyledons: The Families and Genera of Vascular Plants; Kubitzki, K., Rohwer, J.G., Bittrich, V., Eds.; Springer: Berlin/Heidelberg, Germany, 1993; Volume 2, pp. 237-242.

44. Bradstock, R.A.; Hammil, K.A.; Collins, L.; Price, O. Effects of weather, fuel and terrain on fire severity in topographically diverse landscapes of south-eastern Australia. Landsc. Ecol. 2010, 25, 607-619. [CrossRef]

(C) 2020 by the authors. Licensee MDPI, Basel, Switzerland. This article is an open access article distributed under the terms and conditions of the Creative Commons Attribution (CC BY) license (http://creativecommons.org/licenses/by/4.0/). 